\title{
Fergana as FATA? Central Asia after 2014 - Outcomes and Strategic Options
}

\author{
Ted Donnelly *
}

\section{Introduction}

After more than a decade at war, the world's most powerful military withdrew its combat forces from Afghanistan. Having variously pursued counterinsurgency and counterterrorism strategies, the invading force had not been victorious, but neither had it been defeated. The superpower left behind a friendly Afghan government and reasonably well-trained and well-equipped Afghan security forces. It also left behind insurgents, including not only local Afghans but also foreign Islamists, whose capabilities had been disrupted and degraded but not defeated. The superpower continued to support its Afghan government allies, rendering financial support, military training, and technical assistance to address the insurgency. However, after two years, new political and fiscal realities forced the superpower to cease its support. Afghanistan descended into civil war, in which Islamic extremists prevailed. In return for their support, the new Islamist government repaid its foreign jihadist allies with safe haven, which they used to train and plan attacks against the United States, among others. They also destabilized Afghanistan's neighbors, creating conditions in which violent extremism thrived. To the north of Afghanistan, violent extremist organizations focused their attention on the Fergana Valley, a region that lies at the heart of Central Asia and is shared by three states. ${ }^{1}$

The scenario described above began in 1989, and the withdrawing superpower was of course the Soviet Union and its Red Army. Drawing historical parallels can be dangerous, and other significant geostrategic events were certainly at work from 1989 to 1991 that affected post-Soviet Afghanistan and its neighbors. ${ }^{2}$ Nonetheless, the Soviet withdrawal from Afghanistan holds lessons for the United States when it will eventually transfer security duties to the Afghan government in 2014. As B.H. Liddell Hart famously wrote, "the object in war is to attain a better peace." ${ }^{3}$ Yet, after thirteen years

Any views expressed in this article are those of the author and do not necessarily represent the official position of the United States government, the Department of Defense, or the United States Army.

1 In the context of this article, the terms "Central Asia," "Central Asian States," and "CAS" all refer only to the former Soviet Republics of Uzbekistan, the Kyrgyz Republic, Tajikistan, Kazakhstan, and Turkmenistan. This is also the U.S. Department of Defense definition of the region.

2 Shortly after the Soviet withdrawal from Afghanistan in 1989, the Soviet Union began its final collapse. Unrest and upheavals in the Eastern European states of the Warsaw Pact initially drew Soviet attention toward Europe. By December 1991, the Soviet Union itself dissolved. Soviet/Russian Federation assistance to Afghanistan declined precipitously and ended shortly thereafter.

3 B.H. Liddell Hart, Strategy (London: Faber \& Faber, 1954), 353. 
of war in Afghanistan, the United States faces a potential post-2014 "peace" in which Central Asia is less stable, harbors more terrorists, and presents a greater security threat to the U.S. than on 10 September 2001. Ironically (and tragically), a war originally begun to eliminate violent extremist safe havens in Afghanistan could have the unintended consequence of producing violent extremist safe havens in the Central Asian States (CAS), just to the north. This is a realistic and even likely future scenario, in part because U.S. strategists have insisted on viewing a strategic problem through a purely operational lens. However, this is not the only future, and it is not inevitable. The proper strategy can prevent this outcome. The analysis presented in this essay will describe the most likely effects of the 2014 U.S. withdrawal from Afghanistan on the Central Asian States, focusing on the Fergana Valley - the strategic center of gravity of the region. It will then evaluate U.S. policy options and recommend a post-2014 strategy.

\section{The Significance of Central Asia}

In 2001, the U.S. necessarily entered Afghanistan without an exit strategy. Furthermore, in over a decade of fighting, it has yet to develop a theater strategy that adequately addresses the vast region of former Soviet republics to the north of Afghanistan. From the beginning, U.S. theater strategy has approached Central Asia from a purely short-term, operational perspective. In 2001, the U.S. needed airbases to transport troops and supplies and to base fighters, tankers, and cargo planes, and successfully negotiated to establish them in Uzbekistan and the Kyrgyz Republic. ${ }^{4}$ Later, when ground supply lines through Pakistan came under increasing pressure, the U.S. established the "Northern Distribution Network" (NDN), a complex of ground supply routes running from Europe to Afghanistan, transiting various Central Asian states. The U.S. was quick to assure the Central Asian governments and nervous neighboring regional powers Russia and China that U.S. interests in the region were temporary and existed only in the context of Operation Enduring Freedom (OEF) in Afghanistan. This message has been reiterated frequently, as this "temporary" U.S. presence in the region has now exceeded ten years. Thus, since 2001, U.S. military strategists have treated this

4 Shortly after 2001, the United States Air Force established two support bases in the Central Asian States: one in Kharshi-Khanabad, in southern Uzbekistan (known as "K2"), and the other at the Manas International Airport in Bishkek, Kyrgyz Republic (initially "Ganci Air Base," named after the New York City Fire Chief killed on 11 September 2001). K2 was the primary base used to support operations in Afghanistan until 2005, when disputes over rent payments and U.S. criticism of Uzbek government human rights abuses at Andijon (in the Fergana Valley subregion) led the government of Uzbekistan to evict the United States. Since December 2005, "Ganci" (given the cumbersome new title of "The Transit Center at Manas International Airport," or TCMIA, in July 2009) has been the only U.S. support facility in Central Asia, and as such its importance has increased significantly. For their troubles, Central Asian governments received marginally more U.S. assistance, more frequent highlevel visits (mostly military), and occasionally some respite from criticism on human rights and democracy. 
region solely as a geographic and occasionally political obstacle to operations something to be transited or crossed en route to or from Afghanistan. In accordance with the current strategy, when OEF ends, U.S. operational requirements in the region will also end, and Central Asia will cease to be of concern. Current U.S. military strategy in Central Asia is best summarized as "do whatever is necessary to keep our bases and supply routes open until the last U.S. soldier leaves Afghanistan in 2014." ${ }^{5}$

As important as it is to support the war fighters in OEF, the problem with this approach is that it fails to acknowledge the strategic significance of the Central Asian region in its own right. A strategic analysis of the region demonstrates that Afghanistan and Central Asia are inextricably linked, strategically as well as operationally. Strategic success in Central Asia is critical to strategic (not just operational) success in Afghanistan, and vice versa.

It is certainly legitimate to question why the U.S. should fear the prospect of instability in Central Asia after 2014, or even the specter of a Fergana-based Islamic caliphate, given that the U.S. will no longer have operational transit requirements in support of OEF. The answer is two-fold. First, stability in Central Asia is a prerequisite for stability and security in post-2014 Afghanistan. The Federally Administered Tribal Areas (FATA) region of Pakistan provides a useful and relevant example of this point. The FATA region consists of largely ungoverned space and serves as a safe haven for numerous violent extremist organizations, many of which conduct operations in Afghanistan. These groups are a significant source of Afghanistan's present instability, and will remain so after 2014. An analogous region to the north (and one not even nominally friendly to the U.S.) would be devastating to Afghanistan's future, as that country would find itself surrounded by destabilizing regimes. In such an environment, it is inconceivable that Afghanistan could survive as a stable, independent state that does not sponsor or support international violent extremism.

Second, and perhaps more important from a strategic perspective, the Central Asian states have the potential to become what Turkey once was, and what Egypt, Libya, Iraq, and Syria will never be: moderate, secular, Muslim-majority states that are not hostile (and are perhaps even friendly) to U.S. interests. With the right strategy, this outcome is achievable, and without a massive expenditure of resources. The Central Asian states do not require expensive (and fruitless) nation building efforts, nor do they require awkward informational campaigns on the dangers of extremism and the merits of secularism. They do, however, require moderate support to maintain these traits.

While a post-2014 theater strategy should necessarily be focused on Afghanistan and Pakistan, it must not neglect the Central Asian states to the north. As noted above, Afghanistan and Central Asia are strategically linked. Furthermore, the array of problems facing Central Asia is not nearly as intractable as is the set of challenges confronting Pakistan. It is possible between now and 2014 to develop and implement a theater strategy that advances U.S. national interests by protecting Central Asia's stra-

5 James N. Mattis, "U.S. Central Command Posture Statement," presented before the Senate Armed Services Committee on 1 March 2011; available at http://www.centcom.mil/en/aboutcentcom/posture-statement/. 
tegic center of gravity, the Fergana Valley. This will create necessary conditions to ensure strategic success in Afghanistan. Most importantly, in a time of reduced budgets and constrained U.S. international commitments, it is neither fiscally expensive nor a manpower intensive strategy.

\section{Assumptions Regarding the U.S. Withdrawal from Afghanistan}

The analysis presented in this essay proceeds from several assumptions. First, the U.S. combat commitment will end in December 2014 as promised, with security responsibilities transferred to Afghan forces. ${ }^{6}$ While NATO leaders have declared that the withdrawal will be "conditions-based, not calendar driven," that combat operations will be completed by $2014 .{ }^{8}$ Indeed, the withdrawal of U.S. "surge" troops has already begun. If the example of Iraq is any indicator, there will be little domestic political will to extend the U.S. combat commitment beyond 2014, and there could even be pressure to withdraw trainers soon thereafter. Whatever the ultimate date, it will come someday, and U.S. strategy must address an Afghanistan in which U.S. combat troops are not present and Afghan forces have overall responsibility for security.

The second assumption is that U.S. assistance, both military and developmental, cannot and will not continue at its current levels. This is not just a function of budget realities in the United States, but also of fatigue and waning interest among the American people and their elected leaders. The post-2014 strategy must assume that fewer financial and personnel resources will be available for U.S. efforts in the region. Given the first two assumptions, it is also reasonable to assume that the post-2014 Afghan government and its security forces will not control 100 percent of its territory.

Finally, the main regional powers Russia and China are unlikely to support any future U.S. strategy that involves continued U.S. presence and significant U.S. influence in the region. The post-1991 trend of active opposition to U.S. physical presence is likely to continue as it has for the past twenty years, glimpses into leaders' souls and reset buttons notwithstanding.

6 "Combat forces" in this context refers to large conventional units. There remains the possibility, even likelihood, that the U.S. Special Operations Forces will remain active in Afghanistan, and that the U.S. will continue to use drone attacks against high value targets.

7 NATO Public Diplomacy Division, Press Release 155, "Lisbon Summit Declaration Issued by the Heads of State and Government in the meeting of the North Atlantic Council" (Lisbon, 20 November 2010), 2; available at http://www.nato.int/cps/en/natolive/official_texts_ 68828.htm?mode=pressrelease.

8 Barack Obama, Press Conference by U.S. President at the North Atlantic Meeting at the level of Heads of State and Government (Lisbon, 20 November 2010); available at www.nato.int/ cps/en/natolive/official_texts_68828.htm?mode=pressrelease. 


\section{Effects of the U.S. Withdrawal on the Central Asian States}

In light of these four assumptions, what will be the effect of the U.S. withdrawal on the states in Central Asia post-2014? For insights it is worthwhile to briefly return to the Soviet experience mentioned above. The Soviet Union's withdrawal of forces from Afghanistan in 1989 created a power vacuum in the region and precipitated a civil war in that country. The collapse of the USSR itself two years later led to an end to Soviet aid to Afghanistan and to Soviet training and equipping of Afghan security forces. The Taliban won the civil war, and in turn offered its territory to like-minded transnational organizations, including of course Osama bin Laden's well-known Al Qaeda network, but also to lesser-known violent extremist organizations such as the Islamic Movement of Uzbekistan (IMU), which has the goal of establishing a Central Asian Islamic caliphate centered in the Fergana Valley. ${ }^{9}$

To the north, the collapse of the Soviet Union and the subsequent withdrawal of most Soviet security forces from Central Asia shortly thereafter created another power vacuum. Soviet central authority was replaced by five new, weak states that struggled to consolidate power internally and create their own national security forces from whatever scraps the Soviets had left behind. The IMU and related groups thrived in this environment, launching attacks against the government of Uzbekistan in 1999. The IMU also attempted to jump-start its Central Asian caliphate by invading the Kyrgyz Republic from its bases in Uzbekistan and Tajikistan, successfully seizing and briefly holding territory during the "Batken Events" of 1999-2000. ${ }^{10}$

9 U.S. Department of State, Office of the Coordinator for Counterterrorism, Country Reports on Terrorism 2010 (Washington, D.C.: State Department, August 2011). The U.S. Department of State has designated two Central Asian groups as "Foreign Terrorist Organizations": the Islamic Movement of Uzbekistan (IMU) and the Islamic Jihad Union (IJU), itself an offshoot splinter group from the IMU. Also active in the region is Hizb-ut-Tahrir (HuT), an ostensibly nonviolent group that seeks the establishment of an Islamic caliphate in Central Asia. The State Department does not consider HuT to be a Foreign Terrorist Organization, but it is outlawed in all Central Asian States and Russia. As the IMU is the oldest, most capable, and most dangerous violent extremist organization in Central Asia, for the sake of simplicity this analysis refers primarily to the IMU. However, the effects of a U.S. withdrawal from Afghanistan will benefit all Islamist extremist groups in Central Asia, and the recommended U.S. policy option will address them all.

10 In 1999, the IMU launched a military offensive against the Batken region (then part of Osh Oblast) with the objective of severing it from the Kyrgyz Republic and creating an embryonic caliphate. Batken was selected due to its remote location, proximity to Fergana, weak control by Kyrgyz central authorities, and the weakness of Kyrgyz security forces. The IMU successfully seized several villages and inflicted significant casualties on Kyrgyz forces before ultimately being beaten back by Kyrgyz counteroffensives. Batken Oblast is the poorest, most devout, and most remote region of the Kyrgyz Republic. It is a narrow, mountainous region that borders the Fergana Valley to the south. Post-Soviet political geography isolated it from the rest of the Kyrgyz Republic even more than its physical geography. Most Soviet roads ran through the Fergana Valley proper, meaning that to travel from the oblast capital of Osh to most points in Batken required crossing Uzbekistan. Given the poor relations between 
While the IMU was ultimately unsuccessful in these early tactical engagements, it was not defeated strategically, and indeed gained considerable prestige at the expense of the governments of Uzbekistan and the Kyrgyz Republic. ${ }^{11}$ On 11 September 2011, the IMU could be said to have had strategic momentum in the Fergana Valley, despite its recent tactical defeats.

Operation Enduring Freedom stopped the IMU's momentum, and dealt them a severe operational defeat. Although not a specified target of OEF, IMU fighters conducting training and planning operations found their Afghan sanctuaries under attack. The IMU suffered many casualties from U.S. and Coalition attacks, and when the Taliban regime was toppled, they lost their safe havens as well. ${ }^{12}$ IMU activity in Central Asia dropped precipitously in the aftermath of early U.S. and Coalition successes in Afghanistan in 2001 and 2002, and the organization relocated its rear areas to Pakistan, much further from their targets in the Fergana Valley and with U.S. military forces in Afghanistan in between.

As noted above, historical parallels are often imperfect, including this one. Clearly, the collapse of the USSR only two years following the withdrawal of Soviet forces from Afghanistan was a significant factor in the success of both the Taliban and the IMU - one that cannot be overstated. However, it is difficult to imagine a post-2014 scenario in which Afghan security forces control all Afghan territory and make it inhospitable to foreign violent extremist organizations such as the IMU. It is quite likely that the U.S. withdrawal will create another power vacuum, and precipitate another power struggle.

So, whither Central Asia in this scenario? Again, the Soviet experience can only take one so far. The Central Asian states have been independent for more than twenty years and have developed their own governments and security forces. Unlike during the immediate post-Soviet period of the 1990s, they will not have to fight insurgents even as they attempt to create their own nations out of chaos. However, it is also difficult to envision a future scenario in which Fergana-based terrorist groups are not emboldened, empowered, and strengthened by the U.S. withdrawal in 2014. Clearly, the vacuum that will be created by the U.S. departure from the region in 2014 is not nearly as substantial as that left by the Soviet withdrawal in 1991 - as noted, U.S. presence in Central Asia has been minimal, its assistance uneven, and its interest short-term and operational.

Nonetheless, the U.S. withdrawal will have significant effects on the Central Asian states of Uzbekistan, Tajikistan, and the Kyrgyz Republic. ${ }^{13}$ While each has recently

the two countries, movement of military forces through Uzbek territory (i.e., along the most direct routes) is generally not possible.

11 The Uzbek response was harsh, repressive, and disproportional. The Kyrgyz response revealed the incompetence and lack of readiness of Kyrgyz security forces.

12 Richard Weitz, "Storm Clouds over Central Asia: Revival of the Islamic Movement of Uzbekistan (IMU)?” Studies in Conflict and Terrorism 27:66 (2004): 507.

13 The immediate impact on Kazakhstan and Turkmenistan is likely to be less significant. These countries would be impacted only under the "worst-case scenario," discussed below. 
celebrated two decades of independence, all remain weak states. In December 2011, the Kyrgyz Republic inaugurated a democratically elected president, the first peaceful transition of power in post-Soviet Central Asia. Yet that young democracy has significant ethnic tensions in its south, and a weak economy everywhere. Uzbekistan's Soviet strongman holdover, Islam Karimov, is old and sick, with no apparent succession plan in place, making that country less stable than it might appear. Tajikistan has yet to recover from the devastating civil war that it fought in the 1990s in the wake of the Soviet withdrawal, and Tajik military forces suffered significant setbacks battling insurgents in 2010.

Within Central Asia, the effects of the U.S. withdrawal will be strongest in the Fergana Valley subregion. As mentioned above, the Fergana Valley is the strategic center of gravity of Central Asia, owing to its central geographic location, extremely fertile soil, dense population, strong religious influence, instability, and lack of effective control by central authorities. ${ }^{14}$ Its territory is split between three states: Uzbekistan possesses most of the fertile valley floor itself, the Kyrgyz Republic holds the foothills and some major population centers, and Tajikistan controls the approaches. The international borders do not always follow traditional lines between ethnic groups in the region, adding yet another destabilizing factor. While the governments of Tajikistan and the Kyrgyz Republic have generally good relations, there are many local disputes in Fergana Valley border areas. The governments of Uzbekistan and the Kyrgyz Republic have poor relations, making regional cooperation more difficult. The valley's central location, ethnic diversity, and shared political status guarantee that any instability in the Fergana Valley will at least affect these three countries. It is not at all a cliché or overly simplistic to state, "as goes the Fergana Valley, so goes Central Asia."

\section{Potential Post-2014 Scenarios for the Fergana Valley}

Three future scenarios are possible for the Fergana Valley. In the worst-case scenario, the Fergana dominoes will begin to fall immediately after 2014. Following the U.S. withdrawal from Afghanistan, the IMU will launch a full-scale offensive in the Valley. Tajikistan, the Kyrgyz Republic, and Uzbekistan all will fall to Islamists within one to two years. This scenario is as unlikely as it is dire. Even in 1999-2000, weaker Central Asian governments were able to beat back the IMU offensives. Still, it cannot be entirely discounted. Events in the Kyrgyz Republic from April-June 2010 demonstrated just how quickly a seemingly "strong" government can collapse under limited pressure, and just how rapidly the security forces can lose control, and in such a comprehensive manner. Additionally, Tajik military forces suffered significant tactical defeats fighting the Taliban in 2010 and $2011 .{ }^{15}$ Nonetheless, an immediate Islamist takeover of Cen-

14 U.S. Joint Chiefs of Staff, Joint Operation Planning, Joint Publication 5-0 (Washington, DC: U.S. Joint Chiefs of Staff, 11 August 2011). Joint Publication 5-0 defines a "Center of Gravity" as "a source of power that provides moral or physical strength, freedom of action, or will to act. It is what Clausewitz called "the hub of all power and movement, on which everything depends ... the point at which all our energies should be directed."

15 U.S. Department of State, Country Reports on Terrorism 2010, 125-27. 
tral Asia will be possible only if Afghan forces collapse quickly and spectacularly in the post-2014 period.

Even less likely is the best-case scenario, in which stability in Fergana flourishes in the wake of the U.S. withdrawal from Afghanistan. In this outcome, Fergana-centric extremist groups would wither away, disband, or join in non-violent political processes. Violent extremism would then become a rarity or a nuisance, not seriously affecting regional stability. Some critics (domestic and international) of U.S. policy in Central Asia have long argued that U.S. presence is the real source of instability in the region, providing a raison d'être for violent extremist groups. ${ }^{16}$ Presumably, in this view, removing the source (i.e., the U.S.) would remove, or at least marginalize, the problem.

However, this presumption ignores several key facts, namely that the IMU and its ilk significantly pre-date any serious U.S. interest (much less presence) in the Central Asia region, and that the IMU's activity only abated when the U.S. destroyed their Afghan sanctuaries. Furthermore, in a recent and relevant example, violent extremist activity in Uzbekistan did not decline after U.S. forces were expelled from the KharshiKhanabad Airbase in 2005. Additionally, several prominent regional leaders have publicly expressed concern that the U.S. withdrawal from Afghanistan will produce instability in Central Asia. ${ }^{17}$ (An opinion that is also frequently voiced privately by regional leaders and defense and security officials). ${ }^{18}$

Rather, the most likely post-2014 outcome is that the Fergana Valley will increasingly resemble the Federally Administered Tribal Areas (FATA) region of Pakistan. Like the FATA, the future Fergana Valley will consist of significant ungoverned space that would serve as a safe haven, breeding ground, and staging area for violent extremist organizations and militants. The IMU and other extremist groups would use this safe haven, as well as reconstituted rear areas in Afghanistan, to increase Islamist insurgent pressure on secular Central Asian governments.

Indeed, there are clear signs that this outcome has already begun to manifest itself. As discussed, the IMU was dealt a serious blow in 2001 and 2002 with the initial entry of U.S. forces into Afghanistan. However, as U.S. interest in Afghanistan waned and attention focused elsewhere, the IMU gradually rebuilt its organization. When coalition forces limited their operations to the north and east of the country, the IMU found new

16 These conclusions are drawn from numerous formal and informal discussions by the author with regional defense and security officials and civilians in the Kyrgyz Republic from August 2009 to June 2011, and at the George C. Marshall European Center for Security Studies from July 2006 to July 2009.

17 Outgoing Kyrgyz Republic President Roza Otunbayeva expressed this concern publicly; see Rick Gladstone, "Kyrgyzstan Sees Instability at End of Afghan Mission," New York Times (26 November 2011). So did the Russian Ambassador to NATO, the Secretary-General of the Collective Security Treaty Organization, and others. See Joshua Kucera, "Why Russia Fears U.S. Afghan Plan," The Diplomat (18 October 2011).

18 Formal and informal communications between the author and security officials and civilians in the region. 
sanctuaries in the south. Operations in the Fergana Valley area resumed in the Kyrgyz Republic (Osh, Uzgen, Jalalabad, and Bishkek) and in Tajikistan in 2009 and 2010. This trend has continued into the present, with the recent disruption of a planned terrorist strike in the Kyrgyz Republic in October 2011.

As the U.S. expanded its area of operations into the south of Afghanistan in 2007, it again increased pressure on the IMU, and in the process almost perversely increased the presence of the IMU and related groups in the Fergana Valley as they fled areas of intense U.S. military activity in the south. In fact, increased presence of IMU fighters in Fergana is presented as evidence of success in Afghanistan. As coalition forces have pushed into previously uncontested areas in south and west Afghanistan, they have "squeezed the sponge," with the excess "moisture" (violent extremists, in this metaphor) landing in Fergana. Kyrgyz security forces conducted successful operations against violent extremist cells in the Fergana Valley cities of Osh and Jalalabad in the summer of 2009 and again in the fall of 2010, while having lesser success in the southwestern Batken Oblast in the fall of 2009. Tajik security forces did not fare as well, losing a significant percentage of their top counterterrorist unit to extremist activity in the fall of 2010. These events have definitely gotten the attention of senior Central Asian defense and civilian officials.

Clearly, terrorist acts centered on the Fergana Valley continue to trend upwards since 2007. As we have seen, in the context of recent history, Fergana-based terrorist groups tend to increase their activity and have greater success when there is a power vacuum or an Islamist-friendly government in Afghanistan. It is easy to conceive of a future scenario in which the IMU and its terrorist brethren become stronger and increase their activities following the U.S. withdrawal from Afghanistan. The primary difference between the present Fergana and the future Fergana is that after 2014 the IMU and related movements will not face the military pressure on their Afghanistan rear areas that they currently face.

In terms of intent, this "Fergana as FATA" scenario does not differ much from the IMU's current strategic goal of establishing a Central Asian Islamic caliphate centered on the Fergana Valley. Indeed, this outcome continues the post-2007 trend of increased activity in and around the subregion. However, there will be a difference in degree and significance. Without U.S. pressure on their Afghanistan and Pakistan safe havens, Central Asian violent extremist organizations will be able to devote more resources to the Fergana Valley, and will most likely concentrate their efforts there.

Furthermore, the insurgent groups have changed since the 1990s. Just as the U.S. military is smarter, tougher, and more proficient after more than a decade at war, so too are Central Asian extremist organizations. IMU fighters have also had more than ten years to hone their tactics, techniques, and procedures in combat against U.S., NATO, and Afghan forces. These battle-hardened insurgents pose a much greater threat to Central Asia's relatively inexperienced security forces than their predecessors did in the 1990s. Furthermore, after 2014 violent extremist groups will continue to benefit from the now-robust Afghan narcotics trade, which was not the case in the 1990s. It is not an exaggeration to say that after the U.S. withdrawal from Afghanistan, the strategic momentum in the Fergana Valley will again shift to Islamist extremist groups. 


\section{U.S. Policy Options}

The United States has three broad policy options in Central Asia after 2014, which will be discussed below.

Option 1: Total Defense Withdrawal and Reprioritization. Under the current strategy, after 2014 Central Asia will return to its pre-September 2001 status - that is, a region of low priority for the United States, where minimal effort and resources will be expended. Under this option, the U.S. military will withdraw its forces, close its facilities, and revert to a low level of military engagement. Central Asian militaries would occasionally get invitations to international conferences, and would continue to participate in contractor-led computer exercises, but for the most part the U.S. Department of Defense would leave the region behind, treating it as a kind of "Dr. Moreau's Island" on which the Department of State could conduct experiments in democracy and human rights.

A total withdrawal would have its advantages. First, U.S. presence has always been contentious, both within the region and to skeptical neighbors and regional powers Russia and China. At a minimum, completely removing the U.S. military presence would eliminate a favorite theme of Russian Federation-sponsored negative media, which would in turn limit regional discontent. If properly executed, this option could create a major informational success for the U.S.

Meanwhile, freed from the burden of guaranteeing strategic access, U.S. diplomats could focus on other, non-military issues, including stability in the Fergana Valley. However, a complete U.S. withdrawal from and deprioritization of the region would leave U.S. diplomats with few resources and even less influence with which to promote stability in the Fergana. Additionally, the closure of the Transit Center at Manas will have a significant, direct, and immediate negative economic impact on the Kyrgyz Republic, including the loss of local jobs, rent payments, and purchase of local commodities. ${ }^{19}$ Lesser, secondary effects will be felt in Uzbekistan and Tajikistan. A nearsimultaneous reduction of U.S. foreign assistance would create a large, destabilizing economic vacuum.

Militarily, this option would deprive the Central Asian security forces of the successful training and equipping that continues to be provided as a result of the region's current high priority and operational significance for American policy makers. This would leave them unprepared to fight resurgent, battle-hardened violent extremist groups in the Fergana Valley, just when this capability is most required.

A variant of Option 1 could address some of its disadvantages through international action. In "Option 1a," the U.S. role would be the same as in Option 1, but it would work with other regional powers and organizations to fill the power vacuum. The U.S. withdrawal would be preceded by a strong diplomatic push to convince Russia, China, and India to work bilaterally with Central Asian governments to stabilize the Fergana Valley, similar to the way Russian troops helped to secure Tajikistan's southern border

${ }^{19}$ Home page of the Embassy of the United States in Bishkek, Kyrgyz Republic, at http://bishkek.usembassy.gov/tc_recent_contributions.html. 
for many years. Additionally, the U.S. could attempt to work through regional organizations such as the Shanghai Cooperation Organization (SCO) and the Collective Security Treaty Organization (CSTO), both of which are generally well regarded in the region.

Option 1a would hold a certain amount of appeal for U.S. policymakers. It is first and foremost a regional, multilateral solution to a regional problem, and one that would require minimal U.S. resources. It would provide a forum for increased cooperation with Russia under the "reset" policy. However, upon review, Option 1a seems unrealistic. First, on a bilateral basis, Russia, China, and India have different and often competing interests in Central Asia. While regional stability would seem to be generally in all parties' best interests, China has largely focused on its own economic interests in the region, while opting out of any role in regional security or stability. Russia, for its part, has sent mixed signals, deploying a forty-person paramilitary advisory group to assist the Kyrgyz Republic with border security in 2011, but also denying desperate Kyrgyz requests for peacekeepers during the ethnic violence of the "Osh events" of June 2010.

While the U.S. views regional stability in terms of strong, independent states, internally respectful of human rights and externally at peace with their neighbors, it is not clear that the Russian Federation shares this definition. With China already dominating the region economically (a trend that will undoubtedly continue, and even accelerate), Russia's primary value is as a security guarantor. Russia is less interested in ensuring the existence of strong, independent states capable of securing their own borders and their own territory. While Russia fears Islamists on its southern border, it also has a vested interest in security dependency on the part of the Central Asian states.

Additionally, Russia and China have generally opposed U.S. policy in Central Asia for the last ten years, often vehemently. While both will gladly attempt to fill the influence vacuum, it is not likely that they will immediately agree to carry water in support of U.S. interests. Furthermore, when the U.S. leaves the region, it will forfeit a great amount of influence, not only with the Central Asian governments but with the neighboring regional powers as well. U.S. diplomats would have extremely limited leverage with which to convince Russia and China to actively support U.S. interests in the Fergana Valley.

Multilaterally, as the SCO has formally called for an end to the U.S. presence in Central Asia, ${ }^{20}$ it again seems unlikely that this organization would agree to work towards U.S. ends in the region. Meanwhile, neither the SCO nor the CSTO have proven to be effective beyond the level of rhetoric. Thus, while appealing at first glance, Option 1a falls into the "too good to be true" category, as it is extremely unlikely to occur. By relying almost totally on Russia, China, and organizations dominated by these countries, this option also significantly increases the risk that the desired U.S. strategy will fail and that American national interests will not be attained.

20 Shanghai Cooperation Organization, "Declaration by the Heads of the Member States of the SCO," SCO Annual Summit, Astana, Kazakhstan, 5 July 2005; available at www.eurasianhome.org/doc_files/declaration_sco.doc. 
Option 2: Post-11 September 2001 Status Quo. This policy option represents the opposite of Option 1. In this variant, little would change in Central Asia in 2015 and beyond. The region would remain a high priority - although, with the operational justification of military involvement in Afghanistan removed, U.S. policy would finally acknowledge and address the strategic significance of Central Asia in its own right. The U.S. would maintain a substantial military presence in the region, primarily at the Transit Center at Manas International Airport (TCMIA) in the Kyrgyz Republic. Despite recent statements by the newly-inaugurated president of the Kyrgyz Republic, Almazbek Atambayev, that the air base will be closed, the status quo option is viable. The U.S. could in fact negotiate an extension to the TCM agreement, and the government of the Kyrgyz Republic would be receptive if the right terms were offered. ${ }^{21}$

Of course, the requirement to transport large numbers of personnel and many thousands of tons of supplies to Afghanistan would be gone, so the Transit Center would require a new mission, a reconfiguration, and a name change. This "new" U.S. military facility would be reinvented as a regional support platform for U.S. and allied security cooperation, public diplomacy, and counterinsurgency activities. Legacy cooperation programs (Defense Institution Building, Security Sector Reform, military exchanges, limited training and equipping of regional security forces) would continue, but with a more regional focus. In this option, the U.S. Department of Defense would remain the lead agency for U.S. involvement, and the military element of national power would be dominant, as it has been since the events of 9/11. However, diplomatic, economic, and informational activities would continue as well.

The status quo option has the advantage of maintaining a strong U.S. presence (although still predominantly military) in the region after 2014. This presence would not only provide the U.S. with the resources to continue its current level of assistance, but would also demonstrate a continuing commitment to the region, irrespective of operations in Afghanistan. The substantial U.S. presence would continue to provide significant economic benefits as well, and maintaining it would prevent severe short-term, potentially destabilizing economic consequences. ${ }^{22}$

However, the benefits of maintaining a large U.S. military facility in the region after 2014 are far outweighed by the negatives, primarily in strategic communications

21 The Transit Center provides substantial direct (rent) and indirect payments (increased assistance, local purchase, local employee salaries) to the Kyrgyz economy. The U.S. presence also provides a useful foil against Russia, allowing the Kyrgyz to extract greater concessions from them as well. Previous demands that the U.S. vacate the TCMIA have been merely opening positions in the negotiations that followed. In the context of Policy Option 2, the U.S. could make the case to the Kyrgyz government that the TCMIA needed to remain as a platform for U.S. assistance. If the compensation package included construction of a second runway and continued U.S. assistance in turning the Center into an international civilian cargo hub (both longtime Kyrgyz objectives, and the latter already partially-funded by the U.S.), then an agreement could likely be reached.

22 Home page of the Embassy of the United States to Bishkek, Kyrgyz Republic, at http://bishkek.usembassy.gov/tc_recent_contributions.html. 
and diplomacy. Since its presence at the regional air bases was established, the U.S. has repeatedly assured regional governments and concerned neighbors Russia and China, both publicly and privately, that the Transit Center at Manas is only a temporary facility for the support of Coalition military operations in Afghanistan. Any attempt to extend the TCMIA beyond what is required for Operation Enduring Freedom would have a devastating negative impact on the United States' image and reputation in Central Asia. It would confirm regional conspiracy theories and long-standing Russian suspicions of a desire in Washington to establish a permanent U.S. presence, and would be exploited by both Russia and the IMU. While regional governments could be convinced that continuing to host a U.S. military facility is in their best interests, their people are much less likely to accept such an argument.

Furthermore, the requirement to maintain military facilities in the region has largely consumed U.S. diplomatic efforts since 2001, and has overshadowed nearly all nonmilitary engagement and assistance. ${ }^{23}$ Continuing this requirement would ensure that the U.S. military presence would dominate all future significant dialogues, and prevent U.S. diplomats, development experts, and the military from focusing their energy and efforts on issues affecting the Fergana Valley and regional stability.

Finally, the status quo option does not achieve the theater strategic objective. More than ten years of military-dominated regional policy in the region has not produced stability in the Fergana Valley. A successful post-2014 strategy for Central Asia cannot simply continue the operational focus of the past decade-implemented from its primary artifact, the Transit Center at Manas - and expect to gain long-term acceptance in the region.

Option 3: Lessons Learned and Best Practices. There are many lessons to be learned from U.S. interactions with Central Asia over the last ten years. This policy option requires that the U.S. learn from the past decade, thinking strategically while incorporating the best practices and eliminating unsuccessful or damaging legacy approaches.

The first lesson is to think and act strategically, not operationally. To be successful in the long term, the U.S. must take a long-term approach, which requires first acknowledging the strategic significance of the region separate from operational considerations in Afghanistan. Ultimately, the Fergana Valley, as the strategic center of gravity for the region, must be central to any future strategy. Stabilizing the Fergana Valley must be the primary U.S. objective (versus the current "maintain our bases and supply routes" objective).

By making a stable Fergana Valley the primary objective, the U.S. would also align itself with the primary objective of the regional governments. This makes the second lesson easier to implement - namely, that regional governments should have the lead, as partners, rather than the landlord (them)-tenant (us) approach that has been pursued for the past ten years. This goes beyond mere semantics. Paying regional governments

23 A significant amount of diplomatic time and effort (both at senior and working levels) in Central Asia since 11 September 2011 has been focused on basing and transit-related issues. 
"rent" for the use of their territory, whether as direct rent payments for bases, indirect aid packages tied to bases, or tolls for air and ground transit reinforces the short-term nature of the U.S. interest and commitment in the region, which only encourages (literally) rent-seeking behavior and brinksmanship by regional governments. Both the U.S. and the Central Asian governments have a shared strategic interest in a stable Fergana Valley. The strategy should be shared as well, from development to implementation.

However, Russia and China are also part of the region, and the SCO and CSTO are well regarded, if ineffectual, regional organizations. Therefore, the U.S. should advocate and promote Russian, Chinese, SCO, and CSTO participation in the regional strategy. This is not a contradiction of the assertions above - that Russia and China have competing interests and are unlikely to actively participate in a strategy involving the U.S., even if regional governments lead the strategic implementation. It remains true that the U.S. should not expect substantive support from Russia or China, and may even face active opposition (not unlike Option 2 above). Rather, the open stance toward regional participation is primarily for political, diplomatic, and informational purposes.

Regarding information and strategic communications, the third lesson is that silence is the enemy of success in Central Asia. The U.S. must frame the information environment by being public and open about its strategic ends, and about the ways in which it intends to achieve them (with the obvious caveats for operational security and force protection). This goes beyond passive transparency, which has always existed, and would include active, enthusiastic public promotion of the strategy by senior leaders and through public diplomacy platforms. Silence, even in a completely transparent environment, breeds conspiracy theories and negative propaganda. In keeping with the previous lesson, the primary strategic communicators regarding U.S. strategy should be the Central Asian governments themselves, assisted by U.S. experts and resources where necessary.

Next, a large, overt U.S. military presence is counterproductive in Central Asia. Despite the often heroic efforts of public affairs offices and the real and substantive humanitarian work done by U.S. soldiers in the region, the fact remains that the U.S. military is a lightning rod for criticism and conspiracy theories, even in the open and public environment described above. This means that the Transit Center-at least in its current configuration - must be closed, and any subsequent, re-named or re-missioned configurations must feature no involvement by the U.S. military. The security cooperation envisioned in this option does not require a full-time, semi-permanent U.S. military presence (and even if it did, the TCMIA is poorly positioned to support efforts in the Fergana Valley).

Lastly, U.S. assistance efforts over the last ten years have generally been unfocused, disconnected, and overall ineffective. This is particularly true of military-run security cooperation programs, which have generally followed a legacy approach, unrelated to current security realities in the region, but it is also the case with many development, governance, and public diplomacy programs. This is at least in part due to the lack of a strategic approach. 
From a standpoint of security cooperation, certain approaches have been effective at protecting the strategic center of gravity, the Fergana Valley. Specifically, those programs and activities that focus on direct support, such as training and equipping counterterrorist forces, have yielded significant results, measured in successful operations against violent extremist cells. Border security programs have had success even after only partial implementation. Military-funded humanitarian assistance, when executed in conjunction with other U.S. government efforts, has also yielded benefits among the populace. Disaster relief/emergency response programs tend to be noncontroversial, respond to real and significant problems, foster positive relations with the populace, and fill gaps not addressed by other elements of the U.S. presence in the region.

Unfortunately, these approaches have succeeded not because of U.S. military theater strategy, but in spite of it. Rather than reinforcing these successful activities, the current strategy seeks to minimize and prohibit them in some cases. Instead, the vast majority of time and effort is spent on irrelevant and unsuccessful legacy programs. The primary U.S. line of support for Central Asian militaries is to promote broad-based "defense reform," with an eye towards closer cooperation with NATO. U.S. regional strategy development sessions are rife with 1990s clichés: "defense reform," "Defense Institution Building," "Noncommissioned Officer Development," "Planning, Programming, Budgeting, and Execution," and "military professionalism." These programs are not totally without value, and were in fact executed with great success in Eastern Europe. But they are inappropriate, irrelevant, and even counterproductive in the strategic environment of post-2014 Central Asia. At bilateral talks at both the senior and working levels, the atmosphere is often surreal, as Central Asian military and civilian leaders stress contemporary and future Fergana Valley-based security threats, and U.S. leaders respond with pre-2001 platitudes.

Additionally, the U.S. corporate approach to security cooperation has been limited by a narrow focus on partner ministries of defense, neglecting other military units with more significant counterterrorism roles and missions. This misguided and myopic "mirror imaging"-in which U.S. Department of Defense officials only want to deal with their exact counterparts in Central Asian defense organizations- has led to a further misallocation of resources to lower-priority ministries of defense, which in Central Asia have the mission to defend against external state threats (which are not prominent in the contemporary security environment). Successful military cooperation and assistance require working directly and primarily with those units whose primary mission is the elimination of violent extremist threats in the Fergana Valley. Anything else wastes resources and effort.

After 2014, the U.S. must reinforce successful security cooperation, development, and public diplomacy programs, while unsuccessful, misdirected, and/or counterproductive legacy programs must be eliminated. The military-led security cooperation component will be smaller, but must focus on building the capabilities required to secure and stabilize the Fergana Valley: border security and interdiction to isolate the valley from Afghanistan-based insurgents; counterterrorism (focused on those units that fight insurgents in and around Fergana); counternarcotics to cut off funding 
sources to violent extremist organizations; and disaster response. All of these lines of effort have had demonstrated success in the region, but resources are often diverted by a misguided focus on capital city-based legacy programs. Eliminating the legacy programs would release more than enough financial and personnel resources to support Option 3.

Option 3 frees diplomats from the requirement to constantly negotiate U.S. presence and access in the region. It would produce the desired U.S. strategic end state- $\mathrm{a}$ stable Fergana Valley-which is also a long-term strategic objective for each country in the region, as well as for Russia (as opposed to the current operational end states). It would require fewer total resources than Option 2 - the "status quo" choice (but more than Option 1, or "total withdrawal"). However, even with fewer resources, the strategic impact would increase due to more focused efforts.

Option 3 would increase the likelihood that the IMU and other violent extremist groups would begin to actively target U.S. interests, as U.S. policy begins to address them directly. This option holds the greatest risk of U.S. casualties, military or civilian, as U.S. programs push out from urban areas and into the Fergana Valley itself. To date, Central Asian extremist groups have not directly targeted U.S. military facilities or personnel, despite the presence of large, high-payoff, and relatively soft targets in Uzbekistan and the Kyrgyz Republic since 2001. This is almost certainly not a question of capacity, as the IMU has targeted other U.S. interests, including U.S. government offices, throughout Central Asia, most notably the U.S. Embassy in Tashkent in 2004, and has directly targeted host-nation government interests in all three countries. Rather, it is likely that Fergana-based extremist groups are focused on gaining control over the region's center of gravity, the Fergana Valley itself. Current, capital-based U.S. facilities and activities do not directly threaten Fergana-based operations. Indeed, to the extent that they siphon off U.S. and host-nation resources for the arcane, nebulous, defense reform-oriented bilateral security objectives discussed above, current U.S. military activities actually help these extremist organizations. Ironically, the relatively secure Central Asian environment in which the U.S. military has operated since 2001 is a testament to the inefficacy of the current strategy. This will change with Option 3. As U.S. military trainers deploy to the Fergana Valley to work directly with Central Asian counterterrorist forces, they will disrupt violent extremist groups' operations, and they are likely to be targeted. However, this risk can be mitigated with reasonable force protection measures, as are applied elsewhere in areas with similar dangers.

\section{Recommendations}

Clearly, Policy Option 3 offers the best way ahead for U.S. policy in Central Asia, leveraging U.S. lessons learned over the past ten years to craft a regional strategy. Stabilizing the Fergana Valley (and thus the whole of Central Asia) requires that U.S. policy and subsequent implementation efforts be focused on the Fergana Valley. It is also critical that Central Asian citizens perceive U.S. interests and policy in the region to be strategic - that is, having goals beyond short-term operational considerations in support of the military intervention in Afghanistan. This means jettisoning short-term, operationally-focused policy artifacts that Central Asian states and regional powers view 
with suspicion and derision. This will also free up resources (diplomatic, military, and economic) for a focused effort in the Fergana Valley itself, instead of the current, capital city-centric efforts toward development, diplomacy, and security cooperation.

The first step should be to remove the large U.S. military presence and footprint as soon as operations in Afghanistan allow (this could begin immediately, as the U.S. has already begun to withdraw some troops). Nothing symbolizes the U.S. operational approach more than the Transit Center at Manas International Airport, and its closure will herald a new strategic approach. Given the sunk costs and the existence of a first-rate facility, there will be a strong temptation to maintain the TCMIA as a platform for security cooperation. This temptation must be avoided. The Transit Center has a specific purpose, and one that will not be required (or required on a much smaller scale) after 2014. More importantly, with its location just outside Bishkek, far from the Fergana Valley, it is poorly positioned to support a Fergana-based strategy. On a related issue, while the Northern Distribution Network (NDN) is not nearly as contentious as the TCMIA, it is another artifact of the old approach, and its benefits to the people of the Central Asian states are vastly overstated. The U.S. would do well to downplay the significance and impact of the NDN.

Next, all diplomatic, economic, and military efforts should be redirected in support of a comprehensive regional strategy that focuses on stability in the Fergana Valley. This strategy should make every attempt to include Russia, China, and regional organizations, with the understanding that their participation will be unlikely. Fears of "expanded" Russian or Chinese influence are misguided. First, "influence" is not a zerosum "great game." Second, Russian political and social influence in the region is already significant, as is Chinese economic influence. Cooperation with the U.S. might even roll back the Russian and Chinese level of influence in the region.

Option 3 facilitates the maximum application of all elements of national power, and in the optimal proportion. Its focused approach allows the implementation of a more effective strategy with fewer resources than are currently allocated to the region. Because it addresses instability in the Fergana Valley directly, this option has the greatest short-term risk to the U.S. personnel and interests. However, it is the only option that directly and adequately addresses U.S. strategic interests in Central Asia.

\section{Conclusion}

In addition to its operational importance for the Coalition military effort in Afghanistan, the region of Central Asia is strategically significant in its own right, and critical to sustaining success in post-withdrawal Afghanistan. Failure to view the CAS region through a broader, long-term strategic lens jeopardizes success in post-withdrawal Afghanistan, is detrimental to regional security and stability, and increases the likelihood that the U.S. will be drawn back into conflict there on less than desirable terms. 
THE QUARTERLY JOURNAL

\section{Bibliography}

Declaration by the Heads of the Member States of the SCO In SCO Annual Summit, Astana, Kazakhstan. Shanghai Cooperation Organization, 2005.

Gladstone, Rick. "Kyrgyzstan Sees Instability at End of Afghan Mission." New York Times (2009).

Kucera, Joshua. "Why Russia Fears U.S. Afghan Plan." The Diplomat (2011).

Lisbon Summit Declaration Issued by the Heads of State and Government in the meeting of the North Atlantic Council. NATO Public Diplomacy Division, Press Release 155, , 2010.

Mattis, James N.. U.S. Central Command Posture Statement., 2011.

U.S. Department of State, Office of the Coordinator for Counterterrorism, Country Reports on Terrorism 2010 . Washington, D.C.: State Department, 2011.

Weitz, Richard. "Storm Clouds over Central Asia: Revival of the Islamic Movement of Uzbekistan (IMU)?" Studies in Conflict and Terrorism 27, no. 66 (2004): 507. 